\title{
"Pedagogical" Agression in Russian Everyday Communication
}

\author{
Natalia Bragina ${ }^{1,2}$ and Igor Sharonov ${ }^{2}$ \\ ${ }^{1}$ Pushkin State Russian Language Institute \\ Ac. Volgin str., 6 (ulitsa Akademika Volgina, 6), Moscow, 117485, Russia \\ ${ }^{2}$ Russian State University for the Humanities (RSUH) \\ Miusskaya sq. 6, Moscow, GSP-3, 125993, Russia
}

\begin{abstract}
The article is devoted to speakers' responses to inappropriate communicative behavior in Russian everyday communication. The analytic part of the article presents a short review of both classical and modern works on (im)politeness theories, which show that communicative strategies in response to the wrong communicative behavior in a particular context have not been investigated and described sufficiently in modern Politeness theories, investigating face-aggravating communication. The aim of this work is to describe a strategy that we define as "pedagogical aggression", which manifests itself in a variation of impolite answers whose purpose is to "punish" the interlocutor for a communicative error. This strategy is in contrast to what we call "empathy" strategy since — instead of trying to neutralize the interlocutor's error "pedagogical aggression" emphasizes it by "teaching" the addressee to be more considerate in adhering to norms. The material for the research was collected in the Russian National Corpus and analysed by drawing on discourse analysis, pragmatics and (im)politeness theories. The study showed that "pedagogical aggression" is realized in three face-aggravating communicative tactics: (1) a pseudo-question (rhetorical question or a question to the assumptions of an interlocutor), 2) mocking citations from interlocutor's speech, 3) rhymed pseudo-answers. The last tactic was given special attention in the study. We grouped the pseudo-answers in four types corresponding to typical discourse situation. This tactic is based on an unspoken rule, according to which it is permissible to point out in a playful way a communicative error made by the interlocutor. In response to an inappropriate question with this or that interrogative pronoun (where, who, why, etc.), the speaker can allow himself or herself to "punish" the interlocutor with a pseudoanswer, so that he or she will be more careful, more attentive and will not repeat such mistakes. The considered tactic of rhymed pseudo-response is rooted in language with the help of formulaic phrases. The research contributes to (im)politeness theory and the study of communicative interaction.
\end{abstract}

Keywords: politeness, impoliteness, discourse, dialogue strategies and tactics, Russian language

\section{For citation:}

Bragina, Natalia and Sharonov, Igor (2019). "Pedagogical" agression in Russian everyday communication. Russian Journal of Linguistics, 23 (4), 975-993. doi: 10.22363/2312-9182-2019-23-4-975-993. 


\title{
«Педагогическая» агрессия в русской бытовой коммуникации
}

\author{
Н.Г. Брагина ${ }^{1,2}$, И.А. Шаронов ${ }^{2}$ \\ ${ }^{1}$ Государственный институт русского языка имени А.С. Пушкина \\ Москва, 117485, Академика Волгина, 6 \\ ${ }^{2}$ Российский государственный гуманитарный университет (РГГУ) \\ Москва, ГСП-3, 125993, Миусская площяадь, 6
}

\begin{abstract}
Аннотация
Статья посвящена анализу и описанию реактивных стратегий говорящего лица в ответ на неправильное коммуникативное поведение собеседника. В аналитической части статьи дается краткий обзор как классических, так и современных работ по теории вежливости, который показал, что коммуникативные стратегии в ответ на неправильное поведение пока недостаточно полно исследованы и описаны в современных теориях вежливости, касающихся конфликтной и «ликоугрожающей» коммуникации. Целью настоящей работы является описание стратегии, которую мы определяем как «педагогическая» агрессия, проявляющаяся в вариации невежливых ответов с целью «наказать» собеседника за коммуникативную ошибку. «Педагогическая» агрессия как стратегия противопоставлена «эмпатийной» стратегии по отношению к сделанной собеседником ошибке. Выбирающий «эмпатийную» стратегию пытается нейтрализовать ошибку собеседника, а выбирающий стратегию «педагогической» агрессии акцентирует на ней внимание, чтобы научить собеседника быть впредь осторожнее и внимательнее. «Педагогическая» агрессия реализуется в трех тактиках невежливого поведения говорящего по отношению к совершившему коммуникативную ошибку собеседнику. Она предполагает использование: 1) ответных псевдовопросов (риторических вопросов, вопросов обращенных к презумпциям собеседника); 2) передразнивающих цитаций; 3) рифмованных псевдоответов. Наиболее детально в статье описана тактика использования рифмованных псевдоответов. Данная тактика опирается на негласное правило, согласно которому по отношению к совершившему коммуникативную ошибку собеседнику позволительно указать на это в шутливо-игровой форме. Говорящий в ответ на неуместный вопрос с тем или иным вопросительным местоимением (где, кто, почему и т.д.) может позволить себе «наказать» собеседника псевдоответом, чтобы тот впредь был осторожнее, внимательнее и таких ошибок не повторял. Рассмотренная тактика рифмованного псевдоответа укоренена в языке с помощью шаблонных формул. Работа вносит вклад в исследование области коммуникативного взаимодействия и дальнейшего изучения теории вежливости.
\end{abstract}

Ключевые слова: вежливость, невежливость, дискурс, диалогические стратегии и тактики, русский язык

\section{Для цитирования:}

Брагина Н.Г., Шаронов И.А. «Педагогическая» агрессия в русской бытовой коммуникации // Russian Journal of Linguistics. 2019. T. 23. No 4. C. 975-993. doi: 10.22363/2312-9182-201923-4-975-993.

\section{1. Введение}

Начиная с 70-х годов XX века в лингвистике стали активно исследоваться принципы эффективной коммуникации, которые основаны на уважительном отношении собеседников друг к другу. Построенные для описания вежливости концепции с каждым десятилетием расширяют область применения, проникая в различные гуманитарные науки, связанные с социальным взаимодействием: 
лингвистику, социологию, психологию, этнографию, кросс-культурную прагматику, гендерные исследования и т. д. Теория вежливости получила популярность благодаря работам ее «классиков», среди которых в первую очередь следует назвать Дж. Лича (Leech 1983, 2014), П. Браун и С. Левинсона (Brown and Levinson 1987), Р. Лакофф (Lakoff 1989). Обзор истории развития и становления теории вежливости дается в работе М. Лохэр (Locher 2015). Русский языковой материал, связанный с (не)вежливой коммуникацией, анализируется на основе теорий вежливости в работах Н.И. Формановской $(1989,2009)$, Е.А. Земской (1994), О.С. Иссерс (2002), Р. Ратмайр (2003, 2013), М.А. Кронгауза (2008), Т.В. Лариной (2009, 2013, 2015, 2017, 2018), Г.И. Кустовой (2011), Н.Г. Брагиной (2013), Ю.В. Щербининой (2013) и др. Вопросам вежливости и антивежливости посвящен специальный сборник статей «Вежливость и антивежливость в языке и коммуникации» (2018).

В статье рассматриваются этапы становления теории вежливости - «классический» и современный. Выявляется слабо исследованная в теории вежливости область дискурса - стратегия поведения говорящего как реакция на речевое действие собеседника, нарушающее тот или иной принцип коммуникации и вежливости. Предлагается выделить две стратегии построения ответной реплики: «эмпатийную» и «агрессивно-педагогическую». Основное внимание уделяется исследованию одной из тактик «агрессивно-педагогической стратегии», а именно использованию игровых псевдоответов.

\section{2. История вопроса}

В истории формирования теории вежливости можно выделить несколько этапов. В работах «классического» этапа (Leech 1983, 2014; Brown and Levinson 1987; Lakoff 1989) вежливость рассматривается через описание стратегий коммуникативной деятельности, направленных на бесконфликтное общение, через набор требований к говорящему, предохраняющих от экспансии в область интересов и комфортной зоны собеседника. Стратегии и максимы вежливости, описанные в (Leech 1983, 2014; Brown and Levinson 1978, 1987) были представлены, как универсальные правила бесконфликтного и эффективного речевого общения, что позволило изучать на их основе коммуникативные модели разных лингвокультур.

«Классические» концепции вежливости вызвали живой интерес, получили одобрение и стали активно применяться для описания коммуникативного взаимодействия. Однако процесс применения принципов «классических» теорий к реальной коммуникации продемонстрировал их относительную узость и недостаточность, в результате чего данные концепции стали объектом критического анализа (см. [Bousfield, Locher 2008, Culpeper 1996, 2011; Eelen 2001; Spencer-Oatey 2005; Watts 2003]).

Объектом критики «классических» теорий вежливости стали, в частности, статичность модели, на основе которой строятся постулаты и их универсальность, возможность применения к любой социальной ситуации и культуре. Критике подвергается тот факт, что в теориях вежливости как моделях коммуникативного поведения отсутствует эксплицитное описание невежливых стратегий, вырази- 
телей агрессии, грубости и т.д. (см., например, [Watts 2003]). По мнению Илен (Eelen 2001), рассматривающей различные формы грубого коммуникативного поведения, обнаружить адекватный набор критериев невежливости применительно к вежливости невозможно. С ней частично соглашается Калпепер (Culpeper 1996, 2011), утверждающий, что апофатические характеристики, основанные на отрицании положительного признака, представленного типом стратегии или максимой, малоинформативны. Некоторые невежливые стратегии не имеют хороших оснований для противопоставления вежливым стратегиям. Например, грубость и агрессивность очень слабо противопоставлены гармоническому общению, в вежливости отсутствует эмоция, противопоставленная гневу, и т.д. Ряд исследователей предлагает считать адресата высказывания, а не ее автора субъектом оценки высказывания как вежливого или невежливого, а саму оценку рассматривать с учетом всего социокультурного контекста (Watts 2003; Spencer-Oatey 2005 и др.).

В ряде работ исследователи на основании дискурсивного анализа текстов и опросов информантов отмечают, что адресаты речи могут, с одной стороны, оценить внешне нейтральные или вежливые реплики как грубые, обижающие, а с другой стороны, оценивают формально грубые, развязные высказывания как вполне уместные, не вызывающие у адресата отрицательных эмоций (см. обзор работ в [Locher, Watts 2005]). Иными словами, высказывание, вырванное из контекста, не может быть объективно оценено с позиций вежливости или невежливости. Акцент на анализе речевого поведения приводит некоторых ученых к идее исследования невежливости на основе дискурсивного анализа, на иных основаниях, не совпадающих с теми, которые были сформулированы в рамках теории вежливости (см., например, [Eelen 2001: 98-100; Mills 2003]).

Полемика с критическими нападками на теорию вежливости вдохновила Дж. Лича на обновленную версию своей теории (Leech 2014). В ней исследователь отстаивает общность принципов описания вежливых и невежливых высказываний. В обновленной версии представлена Главная стратегия вежливости, состоящая из 10 правил, общая идея которых - ставить собеседника и его интересы выше себя и своих интересов. Противоположная идея - идея невежливости - предлагается как зеркальное перевернутое отражение, постановка говорящего и его интересов выше собеседника и его интересов. Отсюда общий постулат обновленной теории вежливости Дж. Лича: соблюдение принципов вежливости приводит к мирному, бесконфликтному и успешному взаимодействию, а их ненамеренное или намеренное несоблюдение приводит к конфликту и нарушению успешности в коммуникативном взаимодействии, при этом внимание уделяется как языковой, так и социокультурной вариативности (не)вежливости (Leech 2014, Leech and Larina 2014, Larina 2015).

\section{3. Вежливость в реактивных актах дискурса}

Еще одной лакуной в теориях вежливости является, как нам представляется, отсутствие оценки возможных реакций на нарушение стратегий и максим вежливости и коммуникативного взаимодействия в целом. Оценка типовых реактивных стратегий для таких ситуаций с позиций теории вежливости, безусловно, необхо- 
дима, поскольку нарушения стратегий и максим вежливости и коммуникативного взаимодействия в речи - частотное явление.

В работе Г.И. Кустовой (Кустова 2011) рассматриваются некоторые русские псевдовопросы, выражающие недовольство какими-либо «неправильными» (с точки зрения говорящего) действиями, например: Кто тебе сказал такую ерунду?; Я-то откуда знаю?; Тебе какое дело? и др. Цель таких псевдовопросов - научить человека максимально оптимизировать свое поведение, чтобы не мешать другим. Для объяснения распространенности и обоснованности использования таких реактивных фраз автор предлагает дополнить (или развить?) принципы кооперации П. Грайса «постулатами поведения». Данные постулаты передаются в статье в виде требований к говорящему. Перечислим некоторые из них: не запрашивай информацию, которой не располагает адресат; не задавай вопросов, ответы на которые избыточны или очевидны; не запрашивай информацию, на получение которой не имеешь права; не проси о том, на что не имеешь права; не будь излишне доверчивым и некритичным (Там же: 234).

Несоблюдение собеседником перечисленных Г.И. Кустовой постулатов ставит, как кажется, перед говорящим проблему выбора стратегии для ответной реакции на такое поведение. Нам представляется возможным выделить две полярные реактивные стратегии: «эмпатийную» и «агрессивно-педагогическую». При выборе «эмпатийной» стратегии говорящий ставит во главу угла уважительное отношение к собеседнику, ориентируясь на золотое правило нравственности: «Относись к другим так, как хочешь, чтобы относились к тебе». Истоки «эмпатийной» стратегии восходят к этическим представлениям, сформированным в русле религиозных и философских учений Востока и Запада. Например, в христианской этике жития святых описывают ситуации, когда святой нарушал пост, т.е. установленные правила, чтобы не обидеть ближнего, желающего разделить с ним трапезу. Основание для такого поведения находим в словах Апостола Павла в его Послании к римлянам: «Если же за пищу огорчается брат твой, то ты уже не по любви поступаешь... Не губи твоею пищею того, за кого Христос умер» (Новый Завет, Гл. 14). Подобным образом поступают иногда православные священники, когда неосведомленные в христианских правилах жизни люди из добрых побуждений пытаются угощать их во время поста.

Примером эмпатийного поведения может служить исторический анекдот о приеме королевой Великобритании Елизаветой II первого космонавта Юрия Гагарина. Рассказывают, что гость, выпив чаю, достал из стакана кусочек лимона и съел его. Это было очевидным нарушением принятого при дворе этикета поведения, однако королева немедленно повторила действия Юрия Гагарина, чтобы не смутить его. Вслед за ней так же поступили и все присутствующие на приеме.

«Эмпатийная» стратегия в ответ на поведенческие нарушения противопоставлена «агрессивно-педагогической» стратегии - поучению, напоминанию о необходимости правильного поведения, часто сопровождаемому нарушением максим вежливости. Перлокутивный эффект - напоминание или поучение происходит за счет использования разного рода косвенных речевых актов, ломающих гармоничное общение и унижающих в той или иной степени адресата, 
например, псевдовопросов, о которых пишет Г.И. Кустова (Кустова 2011), а также целого ряда других средств. В русской бытовой коммуникации присутствуют обе стратегии, при этом «агрессивно-педагогическая» стратегия распространена и укоренена в виде шаблонных формул. В терминах Брауна и Левинсона данную стратегию можно рассматривать как один из видов «ликоугрожающих» актов (в данном случае - угроза позитивному лицу слушающего) (Brown and Levinson 1987).

На активное использование «агрессивно-педагогической» стратегии в русском коммуникативном поведении исследователи впервые обратили внимание в конце 80-х - начале 90-х годов прошлого века, анализируя речевое взаимодействие продавца и покупателя (см. [Yokoyama 1990, Николаева 1990, Земская 1994]). T.M. Николаева пишет о специфической коммуникации-борьбе, в которой один участник стремится воздействовать на другого, навязать свой взгляд, оценку и при этом унизить собеседника.: Bы еще работаете? - A вы не видели табличку: «Обед»? Автор называет такое взаимодействие «коммуникативным саботажем», цель которого - поставить собеседника в униженное положение, «воспитать» его, заставить быть внимательнее и не отвлекать работника лишний раз ненужными вопросами (Николаева 1994: 225-227). Такая поведенческая стратегия имеет культурную специфику. По крайней мере, она контрастна тем стратегиям, которые приняты в европейский и особенно англосаксонских культурах. Фраза Bac много, а я одна превратилась в характеризующее советское время клише, в котором содержится модель общения продавец - покупатель:

После очередной командировки Лизавета задумалась, почему в любых учреждениях в той же Англии или в Штатах секретари и прочие клерки, включая поличейских, как правило, вежливы и предупредительны, а у нас встречают посетителей, как личных врагов. Отчего-то она решила, что все дело в лингвистике. Наши спрашивают: “Что надо?» И в самом вопросе звучит бессмертное, магазинное: «Вас много, а я одна!» Они спрашивают: «Чем могу помочь?» И уже в сам вопрос включено личное участие (Е. Козырев. «Дамская охота»).

К «агрессивно-педагогической» стратегии можно отнести и упреки, о которых пишут Т.В. Булыгина и А.Д. Шмелев (Булыгина, Шмелев 1997а: 420-426). Авторы утверждают, что упреки используются для того, чтобы заставить собеседника понять свою ошибку, пробудить в нем угрызения совести.

\section{3. Исследование}

В ходе анализа существующих работ и исследования языкового материала нами было выделено три тактики «агрессивно-педагогической» стратегии, предполагающие использование: (1) ответных псевдовопросов (риторических вопросов и вопросов, обращенных к презумпциям собеседника, его исходным предположениям); (2) передразнивающих цитаций; (3) рифмованных псевдоответов.

Первые две тактики уже получали освещение в ряде лингвистических работ (см. [Арутюнова 1986; Кустова 2011; Ратмайр 2013; Шатуновский 2016; Брагина 2018]). Реферативный обзор перечисленных работ представлен в подразделах 3.1 и 3.2. В подразделе 3.3 представлены результаты описания третьей тактики рифмованных псевдоответов. 


\section{1. Использование ответных псевдовопросов (риторических вопросов и вопросов, обращенных к презумпциям собеседника)}

Псевдовопросы находят выражение в качестве реакции на неправильно построенный, с точки зрения говорящего, речевой акт собеседника - вопрос или побуждение. Г.И. Кустова в работе, посвященной риторическим вопросам, заключающим в себе отрицательное утверждение, указывает, что данная тактика заставляет собеседника понять, что он совершил ошибку, нарушил негласные правила коммуникации, которые эксплицируются автором на основе анализа типовых диалогов (Кустова 2011). Ср.:

- Они женятся. - Кто тебе сказал такую ерунду? / Что за ерунда? / Что за глупости? (= Это ерунда, глупости).

- Где Сережа? - Я-то откуда знаю? (= Я не знаю и мне неоткуда об этом знать). /

- Что ты меня-то спрашиваешь? (= Не спрашивай у меня). / - Что я, слежу за ним, чтол ли? (= Я за ним не слежу).

В таких диалогах говорящий одновременно с риторически выраженным отрицательным утверждением коммуникативно «наказывает» собеседника, заставляя его тем самым быть осторожнее и внимательнее при построении вопроса или побуждения.

В работе (Брагина 2018) рассматривались ситуации неверного, с точки зрения говорящего, обращения к нему, которое приводит к использованию говорящим риторического вопроса, построенного по стереотипной фразеосхеме: Как(ая)ой я тебе $X$ ? Автор статьи рассматривает три коммуникативные ситуации:

Ситуация 1. Собеседник использует ласковое, фамильярное обращение. Говорящий не готов к сближению; оценивает такое обращение как неуместное:

— Антоша... Это был точно голос Зои. Правда, она меня так никогда не называла. - Какой я тебе Антоша? - возмутился я. (А. Приставкин. «Вагончик мой дальний») (= Я тебе не Антоша).

Ситуация 2. Собеседник использует нестатусное обращение. Говорящий недоволен, подчеркивает свой статус, чтобы сохранить дистанцию между собой и собеседником:

- Нет, хозяин! Я не в согласьи... - Какой я тебе хозяин! - поднял голос Пугачев. — Ть раб мой, а я твой иарь... (В.Я. Шииков. «Емельян Пугачев») (= Я тебе не «хозяин»).

Ситуация 3. Собеседник использует родственное обращение к говорящему, который не является родственником и не согласен с указанием на возраст:

- Дядя Миша, задымить е? - Какой я тебе, к дьяволу, дядя? Племянничек выискался! (Ф. Абрамов. «Дом») (= Я тебе не «дядя»).

Кроме риторического вопроса, содержащего в себе только отрицательное утверждение, в дискурсе встречаются также ответные вопросы, обращенные к презумпциям собеседника. Рассмотрим пример, который анализируется в работе (Шатуновский 2016). Автор рассматривает диалог:

— Дайте «Огонек». - А где вы видите «Огонек»? 
И.Б. Шатуновский толкует ответный вопрос следующим образом: ₹ 'Вы же не видите «Огонек», следовательно, его нет, поэтому я не могу дать вам его, и вообще, прежде чем спрашивать, надо посмотреть, что есть на витрине' (Шатуновский 2016: 279). Говорящий вопросом побуждает собеседника самому убедиться в том, что его вопрос бессмыслен, что его исходные предположения о наличии журнала были ошибочны.

Использование риторических вопросов и вопросов к презумпциям, как кажется, стало постепенно уменьшаться под воздействием смены экономической модели общества и влиянием западной корпоративной вежливости (см. Ратмайр 2013). Однако это не означает, что они совсем ушли из бытового общения. Забавный пример вопроса к презумпции приводит в ленте Фейсбука лингвист Дмитрий Сичинава, потерявший как-то дорогу к поездам на вокзале:

Далеко идем, - сказала женщина в форме, сидящая на стуле. - Простите? - Далеко идем! - в тоне было что-то настойчивое. - Извините, я не понимаю. Кто и насколько далеко идет? Ее глаза медленно остановились на моем лице. С ужсасом она смотрит на меня несколько секунд. - Вы что (с усилием), русского языка совсем не понимаете? - Русский язык я понимаю, но «далеко идем» нет. - Ну, идете, то есть, идете вы далеко, куда вы идете, молодой человек? - А. (Показываю над головой). Вот тут написано «к поездам». К поездам и иду. - А тут кроме туалета ничего нет. А туалет у нас (с ленинской усмешкой) платный. https://www.facebook.com/mitrius?fref $=$ search\& tn $=\% 2 \mathrm{Cd} \% 2 \mathrm{CP}-\mathrm{R} \&$ eid $=\mathrm{ARB} 2 \mathrm{n}$ XxtyQ80CZ4d7abnL_9116tiCkIk8tPNfwTK7cgeIC4ERhdBRJeWGoJhSErdfJUzw2VHz ArybahB.

Итак, неправильно построенный вопрос или торопливое побуждение собеседника может приводить к использованию псевдовопросов - риторических вопросов и вопросов к презумпциям, заставляющих собеседника смущаться, извиняться, чувствовать себя неловко. Говорящий при помощи такой агрессивной реакции «обучает» собеседника не пытаться изменить установленные границы в отношениях между ними.

\section{2. Использование передразнивающих цитаций}

Вторая тактика «агрессивно-педагогической» стратегии - реакции на реплику собеседника, при которых говорящий повторяет с другой интонацией услышанную реплику собеседника или ее часть для выражения неодобрения, протеста. По мнению Н.Д. Арутюновой, выражаемый таким образом протест говорящего «может быть вызван такими параметрами воспроизводимой чужой речи, как истинность, обоснованность, уместность, адекватность, корректность, ясность, стилевые характеристики, выбор слов, способ обращения и т.п.» (Арутюнова 1986: 50). Н.Д. Арутюнова анализирует и классифицирует разновидности передразнивающей цитации. Приведем иллюстрирующие примеры из ее статьи:

- Пускай уходит! - Пускай уходит! Это легко сказать - пускай уходит! Его сюда привели, чтобы вы сумели воспитать его человеком, а вы говорите - пускай уходит.

- Учишь тебя, учишь, а все без толку. - Без толку, без толку. Заладил.

—Я никуда не поеду. — «Не поеду», «не поеду». А что же делать с билетом? 
Использование тактики передразнивающих цитаций агрессивно воздействует на собеседника, с помощью этой тактики говорящий оценивает мнение или решение собеседника как торопливое и несерьезное, заставляя адресата речи впредь быть осторожнее и внимательнее при выражении мнения, выборе подходящего слова и т.д.

\section{3. Использование рифмованных псевдоответов}

Тактика использования рифмованных псевдоответов - это особый способ воспитательного «наказания» собеседника, который выражается в игровом укоре при помощи коммуникативно неинформативного, абсурдно-игрового ответа. Как известно, вопросы с позиций теории вежливости являются обязывающими, и потому не очень вежливыми речевыми актами (Leech 1986). Особенно это касается вопросов, относящихся к личной сфере говорящего. Этим объясняется, например, несколько устаревающая в настоящее время в русской дискурсивной культуре «деликатная» тактика, требующая от спрашивающего оформлять вопрос менее определенно, использовать вместо частного вопроса общий вопрос (см. об этом, например, в (Булыгина, Шмелев 1997б: 270).

Вместо Куда собрался? задают вопрос Далеко ли собрался?

Вместо Где живешь? - Далеко ли (отсюда) живешь?

Вместо Откуда приехали? - Издалека приехали?

Вместо Когда вы там были? - Давно ли вы там были?

Вместо Сколько у вас детей? - Много ли у вас детей?

Вместо Сколько вы за это заплатили? - Дорого вы за это заплатили? и т.д.

Данная тактика дает собеседнику возможность выбора при ответе. Собеседник может, если сочтет задающего вопрос человека «своим», неопасным, достойным быть включенным личную зону и т.д., ответить конкретно куда именно, где именно, сколько именно и т.д., а может уклончиво подтвердить/опровергнуть предположение собеседника, выраженного в общем вопросе: Да, далеко / Hem, не очень далеко и т.д.

В случаях, когда собеседник, с точки зрения говорящего, слишком неосторожно вторгается в его личную зону, используя вопросы с вопросительными словами где, куда, почему, он может получить абсурдно-игровой рифмованный псевдоответ, например: Откуда ты это знаешь? - От верблюда. Часто псевдоответу предшествуют передразнивающие цитации - дважды повторенное вопросительное слово: Где она? - Где, где... В Караганде. Такие реплики имеют характер эпатажного уклонения от информативного ответа. Псевдоответ строится на фонетическом уподоблении вопросительному слову в высказывании собеседника. Это своеобразное «травестирование» инициирующей реплики, использование данной тактики ставит собеседника в позицию ребенка, которого необходимо воспитывать, учить тому, когда, кого и как можно спрашивать.

Распространенность таких ответных форм с их ритмической структурой может быть объяснена только популярностью рассматриваемой тактики в русской дискурсивной культуре. Сами рифмованные псевдоответы и их прагматические 
свойства привлекали внимание лингвистов, хотя детальный дискурсивно-прагматический анализ таких единиц пока не проводился. А.Н. Баранов и Д.О. Добровольский (Баранов, Добровольский 2008) относят рифмованные псевдоответы в особый класс фразеологизмов - речевых формул-ответов. И.А. Шаронов включает их в состав функционального класса коммуникативов - стереотипных ответных реплик диалога (Шаронов 2009, 2015). Данные единицы обобщенно рассматривались как манифестанты мнимого ответа, насмешливый отказ-дразнилка, балагурство в работах (Бондаренко 2004; Голев 2005; Мечковская 2009). Основной прагматической функцией ответных реплик этого типа исследователи считают поучающее указание собеседнику на неуместность его вопроса.

\section{4. Анализ материала}

В задачу исследовательской части статьи входит дискурсивный анализ рифмованных псевдоответов, используемых в бытовых диалогах. Анализ проводился на материале из Национального корпуса русского языка (НКРЯ) (www.ruscorpora.ru). Общий объем собранного материала составил более двухсот диалогов.

По способу выражения рифмованные псевдоответы можно разделить на два типа. Первый тип - это псевдоответы, выраженные соотносительными местоимениями, которые образуют парные конструкции с вопросительными местоимениями в инициирующих репликах. Вопросительное слово как бы продуцирует «отраженный» ответ: Чего? — Того!; Когда? - Тогда; Зачем? - Затем!; Куда? - Tуда!

Второй тип - это псевдоответы, выраженные речевыми формулами. Такие формулы состоят из двух и более компонентов. Как минимум один из них является полнозначным словом: Откуда? — Oт верблюда; Нy? - Баранки гну! Формулы имеют непрозрачный смысл и как следствие - высокую степень идиоматичности.

Приведем несколько примеров, иллюстрирующих оба типа псевдоответов. Первый тип:

(1) - Ну и чего? - Tого. Возьмет он нас бригадой грузчиков - вот из любви $\kappa$ футбольному искусству, так сказать. Не сыр, конечно, в масле, жирком не запльвем, зато буханка в день железно (С. Самсонов. «Одиннадцать»).

(2) - Зачем президенту Ельцину учить эстонскую грамматику? - Затем! Иначе с работы погонят! - Послушай, ты что-то путаешь. (В. Левашов. «Заговор патриота»).

(3) - Куда? - Туда! Остонадоели! (А. Измайлов. «Трюкач»).

Второй тип:

(4) - Геннадий, откуда у вас самолет? - От верблюда! Вот этого! - с ульюкой отвечает Геннадий и показывает для рекламы пачку сигарет «Кемел». (Г. Горин. «Иронические мемуары»).

(5) - Есенин был запрещенный?.. Почему? - По кочану, - отшутилась она и строго сказала: - Мог бы, между прочим, и написать сочинение: <...> «За что я люблю свою Отчизну». Эпиграфы подсказываю. Сразу два. «Люблю Отчизну я, но странною любовью» и второй: «Кто живет без печали и гнева, тот не любит Отчизны своей» (В. Крупин. «Закрытое письмо»). 
В данной статье мы ограничимся анализом единиц второго типа - наиболее распространенных речевых формул, характеризующих невежливое речевое поведение. В корпусе они представлены с разной степенью частотности. Перечислим единицы вместе со стимулирующими их репликами, начиная от более частотных согласно НКРЯ (в скобках указано количество обнаруженных в корпусе ситуаций употребления каждой единицы), к менее частотным:

Откуда? - От верблюда (42);

Почему? - По кочану (да по капусте) (25);

Кто? - Дед Пихто! (9) / Конь в пальто (10);

Где? - В Караганде (6) / У тебя на бороде (детск.) (2);

Ну? - Баранки гну (9).

Дискурсивный анализ материала позволил выявить типовые ситуации использования рассматриваемых единиц, мотив и интенции автора ответной реплики, маркирующей его недовольство собеседником. На основании характера допущенной, с точки зрения говорящего, прагматической ошибки охарактеризована разная степень такого недовольства.

Ситуацией использования игрового псевдоответа является бытовой неформальный диалог, в процессе которого собеседник задает вопрос, который вызывает недовольство говорящего. В зависимости от используемого в инициирующей реплике вопросительного слова следует соответствующий рифмованный псевдоответ.

Мотивом для употребления игрового псевдоответа служит допускаемая, с точки зрения говорящего, ошибка, неправильное поведение собеседника: недогадливость собеседника, нарушение им социально-возрастных ограничений или личной зоны говорящего и др.

Интенция рифмованного псевдоответа зависит от степени близости собеседников и характера отношений между ними. Это может быть намерение говорящего более или менее мягко «наказать» собеседника за наивный вопрос либо же агрессивно запретить задавать вопросы, грубо прервать контакт.

Во всех случаях целью такого агрессивного акта является поучающее унижение собеседника, побуждение его впредь быть коммуникативно более внимательным и осторожным.

Анализ контекстов использования игровых псевдоответов позволил выделить 4 типа ситуаций. Основанием для такого выделения стал характер допущенной коммуникативной ошибки, которая вызвала у говорящего недовольство, что в свою очередь позволило прибегнуть к рифмованному псевдоответу. Рассмотрим последовательно каждую из выделенных ситуаций.

1. Недовольство по причине наивности, недогадливости собеседника.

2. Недовольство по причине нарушения социально-возрастных ограничений или неосторожного вторжения собеседника в личную зону говорящего.

3. Недовольство тем, что собеседник не понимает или делает вид, что не понимает причины раздражения говорящего.

4. Недовольство как форма выражения враждебного отношения к собеседнику в ситуации вынужденной коммуникации. 


\section{1. Недовольство по причине наивности, недогадливости собеседника}

(6) Я: - Почему? Он: - По кочану. Вас что, в школе ничему не учили? (М. Шишкин. «Письмовник»).

(7) - Олька, тьл откуда все это знаешь? - Женя аж напрягся. - От верблюда, засмеялась я. - Мне сегодня сон приснился. Как будто я - девочка из будущего... И мне поручено спасти тебя. (А. Жвалевский, Е. Пастернак. «Время всегда хорошее»).

(8) Не падай, старик: он был стукачом! - Кто? - я совсем запутался в переплетениях карьер. - Конь в пальто! - рассердился Хлесталов. - Не Токарев же! (А. Боссарт. «Повести Зайцева»).

(9) Что сейчас за стольник толкают, я раньше в пять папиросок вколачивал! - Кто толкает? Есть где купить? — попьтался уточнить Анзор. - Кто-кто. Дед Пихто! Барыги, кто ж еще? (М. Гиголашвили. «Чертово колесо»).

(10) Вообще очень хитро маскируются, гады. - Ну? - спросил Горик. - Что «ну»? Баранки гну! Если б мы взяли Володьку в пещеру, он бы проболтался отиу, и тот передал все сведения о пещере в германский штаб. А пещеры играют очень важную роль на войне. Ясно вам, лопухи? (Ю. Трифонов. «Исчезновение»).

Данная ситуация представлена наибольшим количеством употреблений рифмованных псевдоответов. Собеседники - близкие люди, которые общаются неформально. В их диалогах возможны подшучивание, безобидная ирония, использование грубоватой лексики без негативных коннотаций. Рифмованные псевдоответы часто используют взрослые по отношению к детям. И говорящий, использующий ту или иную формулу псевдоответа по отношению к взрослому собеседнику, шутя низводит его до наивного ребенка. Показателен в этом отношении пример (6), в котором говорящий употребляет в отношении своего взрослого собеседника стереотипный встречный вопрос: Bac что, в школе ничему не учили? После «наказания» игровым псевдоответом говорящий может дать содержательный ответ или предложить сделать логический вывод, как в примере (8). Даная ситуация наименее агрессивна при использовании псевдоответов. Говорящий пытается научить собеседника не торопиться с вопросами, а самостоятельно найти ответ, который, по мнению говорящего, легко выводим из совместной области знаний обоих участников диалога.

\section{2. Недовольство по причине нарушения \\ социально-возрастных ограничений или неосторожного вторжения собеседника в личную зону говорящего}

(11) - Большого Быка ты не трогай, - строго сказал Новый Маргарит. - Почему? - По кочану! - Стало быть, тайна? Стало быть (В. Орлов. «Альтист Данилов»).

(12) Я видела такой микроскоп в магазине случайных вещей - четыре с половиной тысячи! — Да ну? - Честное слово. Откуда он у тебя? - От верблюда. А с лисьей шубой разберемся, Маша, голой не останешься. (Б. Кенжеев. «Из Книги счастья»). 
(13) Что ты натворил, а? Где ты есть-то? - Нигде, мам! В Караганде! Сиди спокойно там, не бойся. Я ничего не делал плохого, поняла? Все, деньги кончаются (З. Прилепин. «Санькя»).

(14) - Кто он? - спрашивает меня Катя. - Кто - кто, дед Пихто, - отвечаю я. - И мама молчит, как партизан, - говорит Катя, но я не лезу. Давно знаю: если чего-то не знаешь - значит, тому и не надо знаться (Г. Щербакова. «Моление о Еве»).

(15) - А кто тебе мешает? - Конь в пальто. Что тебе заказать? - Очень любезно, - наморщила она лоб. - Возьми мне пищиу с морепродуктами, мороженое и кофе (В. Валеева. «Скорая помощь»).

Собеседники в данном наборе контекстов - также близкие или знакомые люди, которые общаются неформально. Однако между ними существует социально-возрастная иерархия, есть запретные тематические области, касающиеся личной зоны участника общения. Случайное нарушение в вопросе запретных тематических границ приводит к легкому недовольству говорящего, который псевдоответом не только обрывает развитие темы диалога, но и косвенно указывает собеседнику, что тот совершил коммуникативную ошибку и впредь должен быть осторожнее, чтобы не попадать еще раз в подобную ситуацию. Говорящий произносит реплику строго и делает паузу, передающую желание говорящего прекратить обсуждение темы как запретной. В примере (11) непонимающий собеседник задает еще один уточняющий вопрос - действительно ли тема под запретом, и получает утвердительный ответ. Стоит, однако, отметить, что, «наказав» собеседника, говорящий часто стремится восстановить отношения обещаниями и успокаиваниями, как в примере (12 и 13). Если же этого не происходит, собеседник может все же немного обидеться на бесцеремонность говорящего, как это видно из примера (15).

\section{3. Недовольство тем, что собеседник не понимает или делает вид, что не понимает причины раздражения говорящего}

(16) Остатки тиража пойдут под нож. - Почему? Что-нибудь случилось? По кочану! Кто тебя тянул за язык?! (Е. Чижов. «Перевод с подстрочника»).

(17) Ну и что? Деловая встреча. - Да, знаю я такие деловые встречи. - Oткуда? - От верблюда. — Ты чего такая дерганая? (М. Трауб. «Не вся la viе»).

Как и в предыдущих типовых контекстах, собеседники - близкие или знакомые люди, ведущие неформальный диалог. Они находятся в латентном конфликте и могут испытывать раздражение друг к другу. По мнению говорящего, собеседник совершил серьезную ошибку, обидел его и должен это понимать. «Виновник», задавая вопрос о причине раздражения, получает от говорящего резкий рифмованный псевдоответ, за которым часто следует обвинение. В примере (14) собеседник обвиняется в неосторожности, приведшей к производственным проблемам, а в примере (15) становится объектом подозрений и ревности. 


\section{4. Недовольство как форма выражения враждебного отношения к собеседнику в ситуации вынужденной коммуникации}

(18) - Почему? - Ты мне надоел. - Почему? - По кочану. Иди спать. Я кладу трубку. Звони своей этой насчет свидания. (Е. Белкина. «От любви до ненависти»).

(19) Но веселая девушка уже назвала мне номер (достала, наверно, бумажку, где он записан). - Спасибо, - сказала я. Телефон был - Антона. - Эй! Эй! завопила вдруг девушка. - A вы кто? - Конь в пальто, - сказала я и повесила трубку. (Е. Белкина. «От любви до ненависти»).

(20) Девочка схватила ручку и ловко попала струей в это самое место смыкания ног <...>. Девочка бросила чайник на пол и ушла из дома. - Где у вас аптечка? - кричал дядя. - Где.. Где.. - бормотала она, уходя. - У тебя на бороде. (Г. Щербакова. «Мальчик и девочка»).

(21) Раз он вскрикнул, уже в полупамяти от побоев: «Да где это я?» Усльшиал: «Где, где... В Караганде». И, не помня себя, взмолился: «Что же я вам сделал плохого?!» В ответ только рассмеялись (О. Павлов. «Карагандинские девятины, или Повесть последних дней»).

(22) Давай, по-быстрому встал, собрался и мы отсюда отскочим. Он все еще сидел на моей постели. - Вы кто? - наконеи сказал я. - Дед Пихто, - ответил второй, входя в комнату. - Где твои кроссовки? (А. Геласимов. «Год обмана»).

В данном типе ситуаций собеседники могут быть как хорошо знакомыми, так и абсолютно незнакомыми. Важно то, что они вынуждены вступить в диалог, при этом один из участников настроен враждебно ко второму, что и демонстрирует использованием псевдоответа. В примерах (18), (19) и (20) говорящий (женщина) данной фразой прерывает коммуникацию, выражая тем самым резко негативное и пренебрежительное отношение к собеседнику. Здесь уже отсутствует «воспитательный» компонент, говорящий просто срывает злость на собеседнике. В примеpax (21) и (22) в диалоге участвуют бандиты и их жертва. Бандиты псевдоответами переводят диалог на язык команд, вынуждая собеседника к беспрекословному подчинению.

\section{Заключение}

Настоящее исследование было выполнено в русле дискурсивного анализа. Была рассмотрена реактивная тактика, используемая в ответ на неправильное, с точки зрения говорящего, речевое поведение собеседника. Такую тактику мы называем «педагогической агрессией». Ее применяют в русскоязычной культуре в основном при неформальном бытовом общении.

Данная тактика оценивается носителями языка как невежливая, но возможная, поскольку существует негласная презумпция, согласно которой по отношению к совершившему коммуникативную ошибку собеседнику при неформальном общении позволительно агрессивно-воспитательное речевое поведение. Говорящий в ответ на неуместный, по его мнению, вопрос, выражаемый при помощи одного 
из вопросительных местоимений (где, кто, почему и т.д.), может позволить себе «наказать» собеседника псевдоответом с целью научить его впредь быть осторожнее, внимательнее и таких ошибок не повторять.

Рассмотренная тактика рифмованного псевдоответа укоренена в языке с помощью шаблонных формул. В тех случаях, когда отношения между собеседниками близкие, использование тактики может носить шутливый характер и не приводить к конфликту. Однако говорящий все равно должен при дальнейшей коммуникации как-то объяснить и загладить свой выпад против собеседника. При конфликтном диалоге стереотипные фразы псевдоответа используются для разрыва контакта или перехода на другой режим коммуникации, требующий от собеседника безоговорочного выполнения команд.

Таким образом, рассмотренный материал показывает, что невежливая коммуникация может градуироваться по степени и характеру воздействия псевдоответов на собеседника: от сравнительно слабого, игрового варианта до сильного, резко антикоммуникативного, ликоугрожающего акта. Это в значительной степени зависит от ранее установившегося характера отношений между участниками коммуникации.

Работа вносит вклад в исследование пока еще слабо описанной области невежливого коммуникативного взаимодействия и способствует дальнейшему углублению в изучении общей теории вежливости.

(C) Н.Г. Брагина, И.А. Шаронов, 2019 (c) creative

https://creativecommons.org/licenses/by/4.0/

\section{БЛАГОДАРНОСТИ}

Авторы выражают признательность анонимным рецензентам и редактору за вопросы и замечания, которые способствовали более четкому освещению в работе некоторых ее теоретических положений.

\section{ACKNOWLEDGEMENTS}

We would like to express our gratitude to the anonymous reviewers and the editor for their questions and remarks that let us clarify some theoretical points.

\section{Список литературы / References}

Арутюнова Н.Д. Диалогическая цитация (К проблеме чужой речи) // Вопросы языкознания. 1986. № 1. C. 50 -64. [Arutjunova N.D. (1986). Quotations in dialogue (problems of reported speech). Voprosy yazykoznaniya, 1, 50 - 64. (In Russ.)]

Баранов А.Н., Добровольский Д.О. Аспекты теории фразеологии. М.: Знак, 2008. 656 с. [Baranov A.N., Dobrovol'skii D.O. (2008). Aspekty teorii frazeologii. (Phraseology Theory Aspects). Moscow: Znak. (In Russ.)]

Бондаренко В.Т. Ответные фразеореплики в русской диалогической речи // Русский язык в школе. 2004. № 6. С. 75-77. [Bondarenko V.T. (2004). Otvetnye frazeorepliki v russkoi dialogicheskoi rechi (Idiomatic replies in Russian dialogue). Russkii yazyk v shkole, 6, 75—77. (In Russ.)] 
Брагина Н.Г. Невежливость как ритуал (речевые формулы антикоммуникативного поведения) // Ритуал в языке и коммуникации. М.: Знак; РГГУ, 2013. C. 45-55. [Bragina N.G. (2013). Impoliteness as a ritual (colloquial cliché of a non-communicative behavior). In Ritual v yazyke $i$ kommunikatsii (Ritual in Language and in Communication). Moscow: Znak. 45-55. (In Russ.)]

Брагина Н.Г. Вежливость как невежливость: на стыке разных культурных норм и правил // Вежливость и антивежливость в языке и коммуникации / отв. ред. И.А. Шаронов. М.: PОССПЭН, 2018. С. 38 - 44. [Bragina N.G. (2018). Politeness as impoliteness: on the junction of the different cultural norms and rules. In I.A. Sharonov (ed.) (2018). Vezhlivost' $i$ antivezhlivost' $v$ yazyke $i$ kommunikatsii (Politeness and Impoliteness in Language and Communication). Moscow: ROSSPEN, 38-44. (In Russ.)]

Булыгина Т.В., Шмелев А.Д. Упрек: два вида оценки при вторичной коммуникации // Языковая концептуализация мира. М.: Школа «Языки русской культуры», 1997а. С. 418-426. [Bulygina T.V., Shmelev A.D. (1997a). Uprek: dva vida otsenki pri vtorichnoi kommunikatsii. In Yazykovaya kontseptualizatsiya mira. (Reproach: Two Types of assessment in secondary communication. Language conceptualization of the World). Moscow: Shkola "Yazyki russkoi kul'tury". (In Russ.)]

Булыгина Т.В., Шмелев А.Д. Диалогические функции вопросительных предложений // Языковая концептуализация мира. М.: Школа «Языки русской культуры», 1997б. С. 263-270. [Bulygina T.V., Shmelev A.D. (1997b). Dialogicheskie funktsii voprositel'nykh predlozhenii. In Yazykovaya kontseptualizatsiya mira (Dialogue functions of questions. Language conceptualization of the World). Moscow: Shkola "Yazyki russkoi kul'tury". (In Russ.)]

Вежливость и антивежливость в языке и коммуникации / сост. и отв. ред. И.А. Шаронов. М.: РОССПЭН, 2018. [I.A. Sharonov (ed.) (2018). Vezhlivost' $i$ antivezhlivost' v yazyke i kommunikatsii. (Politeness and Impoliteness in Language and Communication). Moscow: ROSSPEN. (In Russ.)]

Голев Н.Д. Обыгрывание табуизмов в русском лингвистическом фольклоре // Злая лая матерная. М.: Ладомир, 2005. C. 305-333. [Golev N.D. (2005). Obygryvanie tabuizmov v russkom lingvisticheskom fol'klore. In Zlaya laya maternaya (Figurative Usage of Taboo Words in Russian Folklore. Evil obscene swearing). Moscow: Ladomir. 305-333. (In Russ.)]

Земская Е.А. Категория вежливости в контексте речевых воздействий // Логический анализ языка. Язык речевых действий / отв. ред. Н.Д. Арутюнова, Н.К. Рябцева. М.: Наука, 1994. C. 130-137. [Zemskaya E.A. (1994). Kategoriya vezhlivosti v kontekste rechevykh vozdeistvii. In Logicheskii analiz yazyka. Yazyk rechevykh deistvii (Politeness in context of Speech Impact. Logic Analysis of Language. Language Instruments of Speech Acts). Ed. by N.D. Arutyunova, N.K. Ryabtseva. Moscow: Nauka. (In Russ.)]

Иссерс О.С. Коммуникативные стратегии и тактики русской речи. М.: Едиториал УРСС, 2002. 284 c. [Issers O.S. (2002). Kommunikativnye strategii i taktiki russkoi rechi. (Russian Communicative Strategies and Tactics. Moscow: Editorial URSS. (In Russ.)]

Кронгауз М.А. Русский язык на грани нервного срыва. М.: Языки славянских культур, 2008. [Krongauz M.A. (2008). Russkii yazyk na grani nervnogo sryva (Russian Language on the verge of a breakdown). Moscow: Yazyki slavyanskikh kul'tur. (In Russ.)]

Кустова Г.И. Косвенный речевой акт вопроса как средство речевой агрессии и негативной оценки в русской разговорной речи // Вопросы культуры речи / отв. ред. А.Д. Шмелев. Вып. 10. М.: АCT, 2011. C. 229-235. [Kustova G.I. (2011). Kosvennyi rechevoi akt voprosa kak sredstvo rechevoi agressii i negativnoi otsenki v russkoi razgovornoi rechi. In A.D. Shmelev (ed.) Voprosy kul'tury rechi. (Indirect Speech Act as the means of Speech Aggression and Negative Evaluation in Colloquial Russian) Moscow: AST. 229—235. (In Russ.)]

Ларина Т.В. Категория вежливости и стиль коммуникации: Сопоставление английских и русских лингвокультурных традиций. М.: Рукописные памятники Древней Руси, 2009. 512 с. 
[Larina T.V. (2009). Kategoriya vezhlivosti i stil' kommunikatsii: Sopostavlenie angliiskikh i russkikh lingvokul'turnykh traditsii. (Politeness and Communicative Styles: Comparative Analyses of English and Russian Communicative Traditions). Moscow: Rukopisnye pamyatniki Drevnei Rusi. (In Russ.)]

Ларина Т.В. Англичане и русские: язык, культура, коммуникация. М.: Языки славянских культур, 2013. 360 с. [Larina T.V. (2013). Anglichane i russkie: yazyk, kul'tura, kommunikatsiya (The English and the Russians: Language, Culture and Communication). Moscow: Yazyki slavyanskikh kul'tur. (In Russ.)]

Мечковская Н.Б. Отказ: что определяет диктум и модус в отрицательных реакциях на побуждение? // Логический анализ языка. Ассерция и негация / отв. ред. Н.Д. Арутюнова. М.: Индрик, 2009. С. 230-245. [Mechkovskaya N.B. (2009). Otkaz: chto opredelyaet diktum i modus v otritsatel'nykh reaktsiyakh na pobuzhdenie? In N.D. Arutyunova (ed.) Logicheskii analiz yazyka. Assertsiya i negatsiya (Renouncement: Modus and Dictum in Negative Reactions to the Encourage. Logic Analysis of Language. Assertion and Negation). Moscow: Indrik. 230-245. (In Russ.)]

Николаева Т.М. О принципе «некооперации» и/или о категориях социолингвистического воздействия // Логический анализ языка. Противоречивость и аномальность текста / отв. ред. Н.Д. Арутюнова. М.: Наука, 1990. С. 225-235. [Nikolaeva T.М. (1990). O printsipe "nekooperatsii" i/ili o kategoriyakh sotsiolingvisticheskogo vozdeistviya. In N.D. Arutyunova (ed.) Logicheskii analiz yazyka. Protivorechivost' i anomal'nost' teksta. (About Noncooperative Principle or about Sociolinguistic Impact Categories. Logic Analysis of Language. Inconsistency and Abnormality of a Text). Moscow: Nauka. 225-235. (In Russ.)]

Новый Завет, Гл. 14. [Novyi Zavet (New Testament), Chapt. 14. (In Russ.)]

Ратмайр Р. Русская речь и рынок: традиции и инновации в деловом и повседневном общении. М.: Языки славянской культуры, 2013. 456 с. [Rathmayr, R. (2013). Russkaya rech' i rynok: traditsii i innovatsii v delovom i povsednevnom obshchenii. (Russian Speech and Market: Traditions and Innovations in Everyday communication). Moscow: Yazyki slavyanskoi kul'tury. (In Russ.)]

Формановская Н.И. Речевой этикет и культура общения. М.: Высшая школа, 1989. 159 с. [Formanovskaya N.I. (1989). Rechevoi etiket i kul'tura obshcheniya (Speech Etiquette and Communicative Culture) Moscow: Vysshaya shkola. (In Russ.)]

Формановская Н.И. Речевой этикет в русском общении: теория и практика. М.: ВК, 2009. 333 с. [Formanovskaya N.I. (2009). Rechevoi etiket v russkom obshchenii: teoriya i praktika (Speech Etiquette in Russian Communication: Theory and Practice) Moscow: VK. (In Russ.)]

Шаронов И.А. Коммуникативы и методы их описания // Компьютерная лингвистика и интеллектуальные технологии. Вып. 8 (15). М.: РГГУ, 2009. С. 543-548. [Sharonov I.A. (2009). Kommunikativy i metody ikh opisaniya In Komp'yuternaya lingvistika i intellektual'nye tekhnologii. (Communicatives and Methods of Its Description. In Computer Linguistics and Intellectual Tecnologies) Vyp. 8 (15). Moscow: RGGU. 543-548. (In Russ.)]

Шаронов И.А. Поиск и описание коммуникативов на основе национального корпуса русского языка. // Методы когнитивного анализа семантики слова: компьютерно-корпусный подход / под общ. ред. В.И. Заботкиной. М.: Языки славянской культуры, 2015. С. 145-187. [Sharonov I.A. (2015). Poisk i opisanie kommunikativov na osnove natsional'nogo korpusa russkogo yazyka. In V.I. Zabotkina (ed.) Metody kognitivnogo analiza semantiki slova: komp'yuterno-korpusnyi podkhod (Collecting and Analysis of Communicatives on the Base of Russian National Corpus. Cognitive Analysis Methods of Semantics of Word: Corpus approach). Moscow: Yazyki slavyanskikh kul'tur. 145-187. (In Russ.)] 
Шатуновский И.Б. Речевые действия и действия мысли в русском языке. М.: Языки славянской культуры, 2016. 480 с. [Shatunovskii I.B. (2016). Rechevye deistviya i deistviya mysli v russkom yazyke (Speech Acts and Mental Acts in Russian Language). Moscow: Yazyki slavyanskoi kul'tury. (In Russ.)]

Щербинина Ю.В. Речевая агрессия. Территория вражды. М.: Форум, 2013. 400 с. [Shcherbinina Yu.V. (2013). Rechevaya agressiya. Territoriya vrazhdy (Speech Agression. Territory of Animosity) Moscow: Forum. (In Russ.)]

Bousfield, Derek, and Locher, Miriam eds. (2008). Impoliteness in language: Studies on its interplay with power in theory and practice. Berlin and New York: Mouton de Gruyter. DOI: 10.1017/S0047404509990674.

Brown, Penelope (2015). Politeness and Language. International Encyclopedia of the Social \& Behavioral Sciences (2nd ed.). Elsevier Ltd., 326-330. DOI:10.1016/B978-0-08-097086-8.53072-4.

Brown, Penelope, and Levinson, Stephen (1987). Politeness: Some Universals in Language Usage. Cambridge: Cambridge University Press.

Culpeper, Jonathan (1996). Towards an anatomy of impoliteness. Journal of Pragmatics, 25, 349-367.

Culpeper, Jonathan (2011). Impoliteness. Using Language to Cause Offence. Cambridge University Press.

Culpeper, Jonathan, Bousfield Derek, and Wichmann Anne (2003). Impoliteness revisited: With special reference to dynamic and prosodic aspects. Journal of Pragmatics, 35, 1545-1579.

Eelen, Gino (2001). A critique of politeness theories. Manchester: St. Jerome Publishing.

Lakoff, Robin (1989). The limits of politeness: Therapeutic and courtroom discourse. Multilingua, $8,101-129$.

Larina, Tatiana (2015). Culture-Specific Communicative Styles as a Framework for Interpreting Linguistic and Cultural Idiosyncrasies. International Review of Pragmatics, 7 (5) Special Issue: Communicative Styles and Genres, 195-215.

Larina, Tatiana V., Vladimir I. Ozyumenko \& Svetlana, Kurteš (2017). I-identity vs we-identity in language and discourse: Anglo-Slavonic perspectives. Lodz Papers in Pragmatics, 13 (1), $195-215$.

Leech, Geoffrey (1983). Principles of Pragmatics. London: Longman.

Leech, Geoffrey (2014). The Pragmatics of Politeness. Oxford University Press.

Leech, Geoffrey \& Tatiana Larina (2014). Politeness: West and East. Russian Journal of Linguistics, $4,9-34$.

Locher, Miriam \& Richard J. Watts, (2005). Politeness theory and relational work. Journal of Politeness Research. Language, Behavior, Culture, 1 (1), 9-33. DOI: 10.1515/jplr.2005.1.1.9.

Locher, Miriam (2015). Interpersonal pragmatics and its link to (im)politeness research. Journal of pragmatics, 86, 5-10.

Mills, Sara (2003). Gender and politeness. Cambridge: Cambridge University Press.

Spencer-Oatey, Helen (2005) (Im)Politeness, face and perceptions of rapport: Unpackaging their bases and interrelationships. Journal of Politeness Research, Language, Behaviour, Culture 1 (1): 95-119.

Watts, Richard J. (2003). Politeness. Cambridge: Cambridge University Press.

Yokoyama, Olga (1990). Responding with a question in Colloquial Russian. In Yokoyama, O. (ed.). Harvard Studies in Slavic Linguistics, vol. I, 175-194. Harvard University Slavic Linguistics Colloquium: Cambridge, MA. 


\section{Article history:}

Received: 18 January 2019

Revised: 05 March 2019

Accepted: 10 May 2019

\section{История статьи:}

Дата поступления в редакцию: 18 января 2019

Дата принятия к печати: 10 мая 2019

\section{Bionotes:}

NATAliA G. BRAGINA is a Full Professor, Doctor of Philology, Professor at the Department of Russian language arts and intercultural communication at Pushkin Russian Language Institute / Professor of Russian Department, Institute of Linguistics, Russian State University for the Humanities (RSUH). Research interests: cultural semantics, philosophy of language, lexicology, lexicography, phraseology, Internet linguistics, and intercultural communication.

Contact information: NGBragina@pushkin.institute.

ORCID ID: https://orcid.org/0000-0002-0281-2067

IGOR A. SHARONOV is a Doctor of Philology, Chair of the Russian Department, Institute of Linguistics, Russian State University for the Humanities (RSUH). Research interests: pragmatics, discourse analysis, dialogue, speech etiquette, stylistics, phraseology, grammar, interjections.

Contact information: igor_sharonov@mail.ru

ORCID ID https://orcid.org/0000-0002-5553-1533

\section{Сведения об авторах:}

БРАГИНА НАТАЛЬЯ ГЕОРГИЕВНА - докТор филологических наук, профессор кафедры русской словесности и межкультурной коммуникации Государственного института русского языка имени А.С. Пушкина / профессор кафедры русского языка Российского государственного гуманитарного университета (РГГУ). Сфера научных интересов: культурная семантика, философия языка, лексикология, лексикография, фразеология, интернет-лингвистика, межкультурная коммуникация.

Контактная информация: NGBragina@pushkin.institute ORCID ID: https://orcid.org/0000-0002-0281-2067

ШАРОНОВ ИГОРЬ АЛЕКСЕЕВИЧ - докТор филологических наук, заведующий кафедрой русского языка Российского государственного гуманитарного университета (РГГУ). Сфера научных интересов: прагматика, дискурсивный анализ, диалог, речевой этикет, стилистика, фразеология, грамматика, междометия.

Контактная информация: igor_sharonov@mail.ru ORCID ID https://orcid.org/0000-0002-5553-1533 